GLOBAL JOURNAL OF EDUCATIONAL RESEARCH VOL 18, 2019: 57-62

COPYRIGHT@ BACHUDO SCIENCE CO. LTD PRINTED IN NIGERIA. ISSN 1596-6224

www.globaljournalseries.com; Info@globaljournalseries.com

\title{
UTILIZATION OF MODERN ELECTRONIC INSTRUCTIONAL MATERIALS AND BIOLOGY STUDENTS' ACADEMIC ACHIEVEMENT IN CALABAR EDUCATION ZONE, CROSS RIVER STATE
}

IHEJIAMAIZU, CHRISTIANA CHINYERE AND OCHUI ISAIAH

(Received 16, May 2019; Revision Accepted 31, July 2019)

\begin{abstract}
This paper investigated the utilization of electronic instructional materials on secondary school three (SS3) biology students in Calabar, Education Zone Cross River State, Nigeria. The study adopted Expost facto-research design. A hypothesis was formulated to guide the study, and relevant literature reviewed in line with the purpose of the study. A sample of 490 students was used for the study. A checklist and achievement test were instruments used for data collection. Data generated were analyzed using one-way analysis of variance and tested at 0.05 level of significance. The findings showed that utilization of electronic instructional materials significantly influence students' academic achievement in biology. Based on the findings, it was recommended among others that government should ensure effective distribution of electronic types of instructional materials to all public secondary schools presenting candidates for SSCE and NECO to enhance effectual teaching and learning of biology.
\end{abstract}

KEYWORDS: academic achievement, biology, electronic instructional materials, students

\section{INTRODUCTION}

The development of every sector of the modern world is hinged on the advancement in science and technology. It is on realization of this that nations are striving to increase their knowledge and to become more scientifically and technologically efficient. The overriding aim of science education is to educate people for career in this domain to create a scientifically literate population, capable of thinking critically and contributing meaningfully to the democratic decisions about the development.
Biology is one of the Science subjects offered in Nigerian Secondary Schools and is very important to students in science and science related areas. One of the objectives of teaching and learning the subject as contained in the National Policy on education (2013) is to develop in learners, adequate laboratory and field skills. Its study as a discipline is capable of performing vital roles in the economic, industrial and public life of the learners. This results to good health, wealth creation, pest and disease control, human development, agriculture and lots more (lbe \&

Ihejiamaizu, Christiana Chinyere, Department of Science Education University of Calabar, Calabar Cross River State, Nigeria

Ochui Isaiah, Department of Science Education University of Calabar, Calabar Cross River State, Nigeria

(C) 2019 Bachudo Science Co. Ltd. This work is licensed under Creative Commons Attribution 4.0 International license. 
Ukpai, 2013).

Despite the relevance of biology to humanity, it is observed with regrets that students' biology achievement in internal examinations have been dwindling steadily. Moreover, the WAEC chief examiner's reports are evidence that students' achievement in biology in Nigeria has been persistently poor, and the situation is not different in Cross River State. The dire consequences is the trend as seen in economic and time wastage as students will have to re-register for the examinations leading to reduction in the number of students admitted into science discipline. This will further result to shortage of skilled Manpower in science area. According to Udeani (2012), the space of scientific discovery and ability of students to perform science including biology has lacked behind their international peers.

The failure in the subject has spawned a lot of concern among biology educators. Crucial efforts to ameliorate the negative trend over the years appear not to be effectual (Abimbola, 2015). Authors have attributed the problem to students' characteristics, teacher methodology, lack of learning facilities among others (Olufunke 2012; Dinah 2013, Manalanga \& Awelani, 2014).

Electronic instructional materials as defined by Okwelle and Alagoa (2014) are the aids whose devices require electricity to produce clear image and give meaning to reality in teaching -learning process. Examples include; specimen slides, computer labs, PowerPoint slides, simulations, multimedia, video games, internet systems, overhead projectors, microforms, instructional television among others. The authors added that these materials can help students develop functional knowledge of their subject of study as they stimulate learners' interests and curiosity. They enrich the class, save time and overcome classroom barriers (Delmer 2010). Emphasizing the importance of instructional materials to learning, Esu, Enukoha and Umoren (2009) opined that the most effective learning is any approach that provides the learner with the opportunity to interact with what they see, touch, feel, and that the skillful utilization of these materials can transform a dull and difficult class into an exciting one. For effective utilization of any of the listed electronic resources for instructional purposes, Inyang-Abia (2004) stressed that it depends upon teacher capability to handle both the softwares and hardwares as well as the degree of learners' involvement, availability and accessibility of these materials. Rapid advancement in science and technology require individuals to understand scientific processes through the development of appropriate skills and competences especially for global competitiveness in science education. Peter (2010) indicated that effort has been made by government in providing some laboratory equipment in schools, yet Ogunmade, Okedeji and Bajulaiye (2008); Lawal (2010) asserted that the use of modern instructional materials for the teaching and learning of science in the contemporary schools in Nigeria seems to be relatively rare or few. In response to this assertion and the persistent failure in the science of biology, this paper specifically seeks to find out the degree to which utilization of electronic instructional materials impacts on biology students' academic achievement in Calabar education zone, Cross River State Nigeria.

\section{Statement of Hypothesis}

There is no significant influence of electronic instructional materials on academic achievement of students in biology

\section{Literature review}

Modern technology has expanded from use as technology for communication and online entertainment to tools in education for developing cognitive thinking and enriching academic activities. Okwelle and Alagoa (2014) believed that the modern electronic instructional materials can provide the teacher with meaningful and useful source of information; interesting and competitive platforms for conveying information; helps the teacher overcome physical difficulties in presentation of a given concept; explain points, create reality, encourage active participation of learners and save time. Students as well develop functional knowledge, manipulative skills and understanding of their subject of study as the materials facilitate, stimulate curiosity and different learning styles. More so, Esu, Enukoha and Umoren (2009) found that skillful utilization of these materials can transform a dull and difficult class into an exciting class producing effective learning.

Ofili (2012) researched on instructional television utilization for the enhancement of cognitive skills; implication for the challenges of science education in Niger State, Nigeria. The study used quasi experimental design. A sample of 80 students representing SS2 Physics students in the research area was used for the study. Physics Achievement Test (PAT) was used as instrument for data collection. Data collected was analyzed using t-test statistics. The findings revealed among others that instructional television enhanced academic performance of 
physics students. In same vein, Okworo (2010) reported that television and video-tape motivates and stimulates learners to learn materials, which may not be available in the real environment.

Staylor (2010) earlier opined that the use of multimedia, which is the use of two or more instructional media in biology instruction can make difficult and abstract concepts to become real and interesting thereby resulting to meaningful learning.

Nweke, Dirisu and Umesi (2015) corroborating Staylor, examined the effect of synchronized multimedia (MM) on motivation and academic performance of 200 biology students. The study utilized questionnaire and achievement test to collect data. Findings showed a significant difference in the mean score of students taught biology with synchronized $M M \quad(M=51)$ and students who received lesson without synchronized MM (M=23).

Yuvuv, Servet and Levent (2010) studied the predictors of academic achievement and attitude of secondary school students in Bilgi city of Turkey. Survey research design was used and questionnaire used for data collection. Data collected were analyzed using t-test and one-way analysis of variance. Findings revealed no significant relationship between web-based education and students' academic achievement. Speaking on the availability and usability of modern electronic instructional materials in classrooms and laboratories, Adams (2011) and Udeani (2012) lamented that most public secondary schools in Nigeria may be lacking or not have access to these materials, thus teaching science concepts in abstract, the outcome may be poor performance of students in both internal and external examinations such as National Examination Council (NECO) and secondary school certificate examinations (SSCE).

\section{MATERIAL AND METHOD}

The research adopted ex post facto design. A population of 4898 SS3 biology students in eighty one public secondary schools in Calabar education zone of Cross River State was covered. A non-proportional simple random sampling technique was used to draw 490 SS2 biology students from five sampled schools in the area.

\section{INSTRUMENTATION}

A well-structured 20-item checklist on electronic instructional materials designed by the researchers in line with the WAEC minimum standard for establishment of a secondary school biology laboratory and also a 30-multiple choice achievement test with four options were used as instrument for data collection. Respondents were required to indicate the extent to which they utilize the listed electronic instructional materials in their school. A test-retest approach using Pearson Product Moment Correlation Statistics was used to establish the reliability coefficient of the instrument as 0.90. Data collected were analyzed using one-way analysis of variance (ANOVA).

\section{RESULTS AND FINDINGS}

The null hypothesis stated that there is no significant influence of utilization of modern electronic instructional materials on students' academic achievement in biology was tested with ANOVA

One-way analysis of variance of utilization of electronic instructional materials on students' academic achievement in biology

\begin{tabular}{llll}
\hline Levels of Utilization & $\mathrm{N}$ & $\mathrm{x}$ & $\mathrm{SD}$ \\
\hline $\mathrm{HU}$ & 90 & 40.38 & 5.22 \\
$\mathrm{AU}$ & 164 & 38.41 & 4.48 \\
$\mathrm{LU}$ & 236 & 37.29 & 4.21 \\
\hline
\end{tabular}

$\mathrm{HU}=$ High Utilization; $\mathrm{AU}=$ Average utilization; and LU = Low Utilization

\begin{tabular}{lllll}
\hline Source of Variation & Sum of square & Degree of freedom & Mean Square & $\mathrm{F}$ \\
\hline Between Group & 629.865 & 2 & 314.933 & $15.552^{*}$ \\
Within Group & $9,861.746$ & 487 & 20.250 & \\
Total & $10,491.612$ & 489 & & \\
\hline
\end{tabular}

Significant at $0.05 ; \mathrm{df}=(2,487)$, critical $F=3.02$ 
Result of the analysis revealed that 90 students studied in secondary schools with high utilization of electronic instructional materials; 164 students in schools with average level of utilization and 236 students studied in schools with low level of utilization of electronic instructional materials. The means and standard deviation of students' performance in Biology Achievement Test (BAT) were computed based on utilization of electronic instructional materials and statistically compared using one-way analysis of variance. The analysis showed that the f-calculated (15.552) was far greater than the critical f-value of 3.02 at 0.05 level of significance and 2 and 487 degrees of freedom. This implies that the result is significant indicating that utilization of electronic instructional materials has a significant influence on students' academic achievement in Biology.

The null hypothesis was rejected in favour of the alternate hypothesis. Following this result, a post hoc analysis using Bonferroni correction to adjust for multiple comparison revealed no significant influence between high utilization and average utilization ( $\mathrm{t}=0.76)$; no significant influence between high utilization and low utilization ( $\mathrm{t}=1.393)$ and average utilization and low utilization $(\mathrm{t}=0.696)$ on students' academic achievement since all the calculated $t-$ values were less than the critical t-value of 1.960 .

Bonferroni correction to adjust for multiple comparison analysis of utilization of electronic instructional materials on students; academic achievement Confidence Intervals

\begin{tabular}{lll}
\hline Comparison & Mean 1- Mean 2 & $95 \%$ Cl of difference \\
\hline 1: HU vs AU & +10.50 & -42.99 to +21.99 \\
2: HU vs LU & +17.80 & -48.49 to 12.89 \\
3: $L U$ vs AU & -7.30 & -32.48 to -17.88 \\
\hline
\end{tabular}

Statistical Significance

\begin{tabular}{lcl}
\hline Comparison & Significant? $(\mathrm{P}<0.05)$ & $\mathrm{t}$ \\
\hline 1: HU vs AU & No & 0.776 \\
2: HU vs LU & No & 1.393 \\
3: $L U$ vs AU & No & 0.696 \\
\hline
\end{tabular}

\section{DISCUSSION OF FINDINGS}

The null hypothesis, which states that utilization of modern electronic instructional materials has no significant influence on students' academic achievement, was rejected. This implies that utilization of modern electronic instructional materials has positive significant influence on students' learning. The result is in consonance with the findings of (Ofili 2008; Yuvuv et al 2008; Nweke et al 2015) who found a significant relationship between utilization of electronic instructional materials and students' academic performance. The result also agrees with Esu, Enukoha and Umoren (2009); Okwelle and Alagoa (2014) who believed that utilization of electronic instructional materials can cause difficult and abstract concepts to become real and interesting, enhance development of functional knowledge, stimulate learners' interest, curiosity and acquisition of manipulative skills, which do culminate in meaningful learning and improved academic achievement. Students world over are growing up in a world dominated by modern technologies, which are an integral part of their everyday life. Effort in this research to integrate these materials in teaching and learning has provided evidence that modern electronic instructional materials enable students to solve problems and enrich their academic achievement.

The result of the analysis of the eighteen secondary schools in Calabar Education zone further revealed that availability of electronic materials in most public schools is relatively few and scanty. This has confirmed the earlier work of Adams (2011) who indicated that most schools are not digital and that their students may not have access to these modern materials. It is observed with regrets that even the teachers may not have access to these materials. This may affect their lesson delivery and cause it to become only theoretically based and obsolete, which is responsible for academic achievement in biology.

\section{CONCLUSION}

From the analysis of data, it was evident to conclude that students who study in secondary 
schools where modern electronic instructional materials are utilized, do achieve academically higher in biology than students from secondary schools where these resources are not engaged in the learning of biology.

\section{RECOMMENDATIONS}

Based on the finding and the conclusion, the following recommendations were proffered;

1. Government should ensure effective distribution of the modern electronic instructional materials to all public secondary schools presenting candidates for WAEC and NECO. This will ensure hitch free utilization of the available materials in learning biology

2. Government should partner with donor groups such as old boys or girls associations, P.T.A philanthropists and Non-governmental organizations within the location of the schools in terms of the provision of the learning materials. It is only when the materials are available that they can be used.

3. School supervisors and school heads should ensure that students are actively involved in the learning of biology through the utilization of learning resources. Such process will encourage students to do science instead of learning about it.

4. Professional bodies like STAN should intensify regular seminars and workshops and refresher courses for teachers to train biology teachers on how modern learning resources can be used to improve classroom instructions.

5. Biology teachers should be resourceful and innovative in the use of learning resources. Where some of the materials are not provided, teacher should improvise to reinforce learning that will consequently improve academic return.

\section{REFERENCES}

Abimbola A., 2013. The misunderstood world of science towards a technology of perfect understanding of all. $123^{\text {rd }}$ inaugural lecture of University of Illorin (pg 22-31. Unillorin Press

Adams K., 2011. Information technology and communications in educational administration. Owerri: Uche and Sons Publishers

Delmer, T., 2019. Modern Technollogies and Students Academic Performance. Freedom Printing press, Ibadan.
Dinah C. S., 2013. Factors which influence academic performance in Biology in Kenya: A perspective for global competitiveness. International Journal of Current Research 5(12), 4296-4300.

Esu A. E. O, Enukoha O. I and Umoren G. U., 2009. Curriculum development in Nigeria for colleges and Universities. Calabar: Stiffaith Prints.

FRN 2013. National Policy on Education. Abuja: NERDC Press.

Ibe V. S. O, Ukpai P. O., 2013. The role of Biology education in attaining the MDGs in Nigeria in A. Okechukwu (Ed) STAN $54^{\text {th }}$ Annual Conference Proceedings pg 222-228.

Inyang-Abia, M. E., 2004. Curriculum technology for basic education: method, media and their utilization. Calabar Wusen Publishers

Lawal, F. K., 2010. The extent of the use of instructional materials among biology teachers in selected secondary schools in Kano Metropolis. ABU Journal of Vocational Studies, 4(1), 131-135.

Manalanga, C. L and Awelani, V. M., 2014. Exploring factors affecting performance in biology among students at high schools in Lesotho. Mediterranean Journal of Social Science 5(8), 271-278

Nweke O. C, Dirisu C. W. C and Umesi N., 2015. Effect of synchronized multimedia on motivation and academic performance of students in biology. Proceeding of the $1^{\text {st }}$ International Technology, Education and Environment Conference. African Society for Scientific Research (ASSR). PG 240250

Ofili G. S., 2013. Instructional Television Utilization for the environment of cognitive learning skills: Implication for the challenges in Science Education. International Journal of Educational Research 13(5), 1-7. 
Ogunmade T. O, Okedeji S. A and Bajulaiye 2008. The status of resources in secondary science teaching and learning in Lagos, Nigeria. $47^{\text {th }}$ STAN annual conference proceeding, $\mathrm{Pg}$ 14-21.

Okwelle, P. C and Alagoa F. O., 2014. Enhancing teachers' competence in the use of instructional materials in electronics education in senior secondary schools in Nigeria. Research in Humanities and Social Science 4(28), 20-26.

Okworo, G. A., 2010. Effects of teaching strategies in secondary schools students' achievement and retention in Christian Religion using instructional television. Unpublished Ph.D thesis. University of Uyo.

Olufunken, B. T., 2012. Effect of availability and utilization of Physics Laboratory equipment on students' academic achievement in secondary school physics. World Journal of Education 2(5), 1-7

Peter, A., 2010. The roles of audio visual aids in the teaching and learning process. Anambra State University press. Awka.

Staylor J., 2010. Basic principles of multimedia design and development. San Diego: Communication Inc.

Udeani U. N., 2012. Teaching of understanding and application of Science knowledge and processes. Int'l Journal of multicultural education, 1 191-203.

Yuvuv E, Servet B and Levent D., 2010. Factors that influence academic achievement and attitudes in web based education. International Journal of Instruction 1(1), 31-48. 